Turkish Journal of Internal Medicine CASE
$\frac{h t t p: / / w w w . t j i m .0 r g}{\text { ISSN: } 2687-4245}$

\title{
A Case Report of Cutaneous and Systemic Lupus Erythematosus After Bupropion Usage
}

Suat Akgur $^{1}$ (D), Saide Elif Gullulu² (D), Kamil Dilek ${ }^{3}$, Oktay Unsal ${ }^{3}$ (ID), Mehmet Fethullah Aydin ${ }^{3}$ (D), Aysegul Oruc $^{3}$ (D), Abdulmecit Yildiz 3 (D), Mahmut Yavuz ${ }^{3}$, Mustafa Gullulu3 ${ }^{3}$, Alparslan ERSOY ${ }^{3}$

${ }^{1}$ Division of Nephrology, Kutahya University of Health Sciences Evliya Celebi Education and Research Hospital, Kutahya, Turkey ${ }^{2}$ Department of Internal Medicine, Yenisehir State Hospital, Bursa, Turkey

${ }^{3}$ Division of Nephrology, Department of Internal Medicine, Uludag University Faculty of Medicine, Bursa, Turkey

\begin{abstract}
Bupropion is a drug used to smoke cessation. Various complications have been reported after using this drug. In a 58-year-old female patient, skin findings and anti-Ro52 positivity developed after the use of this drug. Later, signs of vasculitis appeared under immunosuppressive therapy. The patient was diagnosed with cutaneous and systemic lupus erythematosus.
\end{abstract}

Keywords: Bupropion, drug reaction, lupus-like syndrome, cutaneous and systemic lupus erythematosus.

\section{Introduction}

Approximately half of the patients with subacute cutaneous lupus erythematosus (SCLE) meet the 1997 American College of Rheumatology (ACR) classification criteria for systemic lupus erythematosus (SLE). However, subsequent studies have demonstrated that 10 to $15 \%$ of patients with SCLE develop severe central nervous system or kidney clinical symptoms due to SLE involvement. ${ }^{1}$ There is a strong association between SCLE, human leukocyte antigen (HLA)DR3, antibodies to Ro/SSA, and polymorphisms in the tumor necrosis factor (TNF)-alpha promoter gene. Anti-Ro/SSA antibody is positive in $80 \%$ of SCLE patients. ${ }^{2,3}$ Many classes of drugs have been implicated in SCLE, including antihypertensive drugs, lipid-lowering agents, proton pump inhibitors, antifungal agents and TNF-alpha inhibitors. ${ }^{4-8}$ Bupropion is a monocyclic antidepressant drug associated with phenylethylamines (amphetamines). The slowrelease formula is used in the treatment of nicotine addiction. The most common side effects are dose-dependent seizures, abnormal liver function, and urticaria. ${ }^{9-11}$ Herein we presented a case of cutaneous and systemic lupus erythematosus which is associated with bupropion usage. 


\section{Case Report}

A 58-year-old woman who was on $300 \mathrm{mg} /$ day bupropion treatment for 4 days for smoke cessation complained of widespread muscle and joint pain, dry mouth, discoid rashes on hands, arms and legs. Prednisolone and azathioprine were started with the diagnosis of SCLE by skin biopsy. Azathioprine was discontinued because of leukopenia. The patient was referred to our center for further evaluations and treatment. In the initial physical examination, body temperature was $36.8^{\circ} \mathrm{C}$, blood pressure was $110 / 70 \mathrm{mmHg}$, respiratory sounds were coarse. There was bilateral hyperemic rash in the lower extremities and tenderness in her knees and ankles. In the laboratory tests the complete blood count (CBC) and urine analysis were unremarkable. Erythrocyte sedimentation rate (ESR) was $60 \mathrm{~mm} /$ hour. Viral serological tests for herpes simplex virus, Ebstein Barr virus, cytomegalovirus, hepatitis $\mathrm{B}$, hepatitis $\mathrm{C}$ and human immunodeficiency virus (HIV) infections were negative. C-reactive protein (CRP) was $1.29 \mathrm{mg} / \mathrm{dL}$ and procalcitonin was negative. Complement levels were in normal ranges and direct-coombs test was negative. The anti-nuclear antibody (ANA) was positive at 1/100 titration end-point, anti-Ro52 was positive. Anti-histone, anti-cyclic citrullinated peptide (anti-CCP) and rheumatoid factor $(\mathrm{RF})$ were negative. Pathergy test was negative. Thorax computed tomography due to dyspnea and hypoxia did not have evidence of pulmonary embolism, but both lungs had groundglass opacities, thickening of the interlobular septa, and occasionally enlargement of the small airways. In the pulmonary function tests and carbon monoxide diffusion test (DLCO), forced vital capacity (FVC) was $1,340 \mathrm{~mL}$, and forced expiratory volume (FEV-1) was $1,030 \mathrm{~mL}$ and DLCO was low. It was considered that pulmonary findings were due to rheumatologic disease involvement. The ophthalmological examination revealed no vasculitis findings like uveitis.

Consequently, drug-related lupus-like syndrome associated with bupropion was considered with the complaints of discoid rashes, myalgia, arthralgia and laboratory findings of positive ANA and anti-Ro52 tests, and elevated ESR. She was discharged with a daily dose of $20 \mathrm{mg}$ prednisolone. The patient was admitted with steroid-induced hyperglycemia 20 days after the discharge. Her serum glucose level was $350 \mathrm{mg} /$ $\mathrm{dL}$ and $\mathrm{HbA} 1 \mathrm{C}$ was $6.5 \%$. A basal-bolus insulin therapy was started with a dose of 10 units insulin aspart at three times a day preprandially and 12 units of insulin glargine once as basal treatment. The patient was receiving $15 \mathrm{mg}$ of prednisolone treatment daily. After 4 months, the patient was re-admitted to the hospital with the complaint of discharge from hyperemic necrotic lesions on the elbows and fingers, while prednisolone treatment continued. The patient was diagnosed with lupusrelated vasculitis. The patient used 3 cycles of cychophamide and mycophenolate mofetil for 3 months. Then 4 doses of rituximab were given once a week at a dose of $375 \mathrm{mg} / \mathrm{m}^{2}$. The discharge at the elbow completely resolved. However, two fingers of her left hand were amputated due to circulatory failure. Prednisolone and hydroxychloroquine were given as maintenance therapy. After 2 years, prednisolone treatment was discontinued. The clinically stable patient is still monitored only by hydroxychloroquine treatment.

\section{Discussion}

Certain drugs may trigger an autoimmune response; most often, these drugs induce autoantibodies, which may occur in a significant number of patients, but most of these patients do not develop signs of an autoantibody-associated disease. In some patients, a clinical syndrome with features similar to SLE may develop, which is defined as drug-induced lupus. ${ }^{12}$ Drug-induced lupus has similarities to spontaneous SLE, but there are some differences in clinical and immunologic features and in the frequency of such features. It is important to know the differences between drug-induced SCLE and drug-induced SLE. ${ }^{13}$ Although there were several systemic findings such as arthralgia and myalgia seen in SLE during this period, drug-induced lupus-like syndrome was primarily considered in our patient. Medications identified as definitely causing drug-induced lupus include procainamide, hydralazine, minocycline, diltiazem, penicillamine, isoniazid, quinidine and anti-TNF alpha therapy (most commonly with infliximab and etanercept), interferon-alfa and methyldopa. ${ }^{14-16}$ The prognosis of drug-induced lupus is generally quite favorable in most case series and in our experience, with disease typically 
resolving after drug withdrawal, even though treatment may be needed for up to several months in some patients. ${ }^{17-19}$ Occasional patients require glucocorticoid therapy, but life-threatening disease is infrequent. ${ }^{20}$

Patients with drug-induced SCLE have antiRo/SSA antibodies, while patients with druginduced SLE usually have antihiston antibodies. In our patient, the anti-histone was negative, but anti-Ro52 was positive. In our patient, SLE was diagnosed due to the development of vasculitis under immunosuppressive therapy. In 2004, Jumez et al. ${ }^{21}$ reported the first cutaneous lupus erythematosus case that worsened with bupropion therapy, and then Cassis et al. ${ }^{22}$ reported another SCLE case caused by bupropion. Recently, a case series of five patients with bupropionrelated cutaneous lupus erythematosus have been reported..$^{23}$ It is stated in the literature that symptoms appear between 2 weeks and 3 months after the use of bupropion. As in our case, there is no case that starts in a short time. There are no cases of bupropion-induced or aggravated SLE in the literature. Naranjo algorithm score was determined 4 and it can be defined as possible drug adverse reaction. In the literature, SLE rash is more emphasized with active smoking. There are no data in the literature about the relationship between smoking cessation and lupus activation.

Vasculitis develops in approximately 11 to $20 \%$ of patients with SLE. ${ }^{24}$ The most common form, occurring in $10 \%$ to $15 \%$ of cases, is urticarial vasculitis. Cutaneous vasculitis was found in $19 \%$ to $28 \%$ of patients with SLE. Vasculitis may also affect small arteries, possibly resulting in microinfarcts of the tips of the fingers, the toes, the cuticles of the nail folds (splinter hemorrhages), and the extensor surface of the forearm and shin. ${ }^{25}$

\section{Conclusion}

The diagnosis of drug-induced lupus should be considered primarily in patients who develop skin findings after the use of bupropion. However, these patients should also be evaluated for possible SCLE, especially if there are some antibody positivity such as anti-Ro52. The appearance of vasculitis findings in our patient during the period of immunosuppressive therapy supported the presence of SLE. As a result, the use of bupropion during smoking cessation therapy may increase disease activity or cause the disease to become evident, especially in patients with SLE.

\section{Conflict of Interest}

The authors declared that there are no potential conflicts of interest with respect to the research, authorship, and/or publication of this article.

\section{References}

1. Sontheimer RD. Subacute cutaneous lupus erythematosus: 25 -year evolution of a prototypic subset (subphenotype) of lupus erythematosus defined by characteristic cutaneous, pathological, immunological, and genetic findings. Autoimmun Rev. 2005;4(5):25363.

2. Lin JH, Dutz JP, Sontheimer RD, Werth VP Pathophysiology of cutaneous lupus erythematosus. Clin Rev Allergy Immunol. 2007;33(1-2):85-106.

3. Marzano AV, Lazzari R, Polloni I, Crosti C, Fabbri $\mathrm{P}$, Cugno M. Drug-induced subacute cutaneous lupus erythematosus: evidence for differences from its idiopathic counterpart. Br J Dermatol. 2011;165(2):33541. doi: 10.1111/j.1365-2133.2011.10397.x.

4. Chong BF, Song J, Olsen NJ. Determining risk factors for developing systemic lupus erythematosus in patients with discoid lupus erythematosus. $\mathrm{Br} \mathrm{J}$ Dermatol. 2012;166(1):29-35. doi: 10.1111/j.13652133.2011.10610.x

5. Grönhagen CM, Fored CM, Linder M, Granath F, Nyberg F. Subacute cutaneous lupus erythematosus and its association with drugs: a population-based matched case-control study of 234 patients in Sweden. Br J Dermatol. 2012;167(2):296-305. doi: 10.1111/j.13652133.2012.10969.x.

6. Srivastava M, Rencic A, Diglio G, Santana H, Bonitz P, Watson R, Ha E, Anhalt GJ, Provost TT, Nousari $\mathrm{CH}$. Drug-induced, Ro/SSA-positive cutaneous lupus erythematosus. Arch Dermatol. 2003;139(1):45-9.

7. Callen JP, Hughes AP, Kulp-Shorten C. Subacute cutaneous lupus erythematosus induced or exacerbated by terbinafine: a report of 5 cases. Arch Dermatol. 2001;137(9):1196-8.

8. Sontheimer RD, Henderson CL, Grau RH. Druginduced subacute cutaneous lupus erythematosus: a paradigm for bedside-to-bench patient-oriented translational clinical investigation. Arch Dermatol Res. 2009;301(1):65-70. doi: 10.1007/s00403-008-0890-x.

9. Fays S, Tréchot P, Schmutz JL, Cuny JF, Truchetet F, Barbaud A. Bupropion and generalized acute urticaria: eight cases. Br J Dermatol. 2003;148(1):177-8.

10. Chiavérini $\mathrm{C}$, Baldin B, Chichmanian R-M, Ortonne J-P, Lacour J-P. Bupropion (ZybanÓ) induced urticaria: 2 cases. Annales de Dermatologie et de Vénéréologie. 
2003;130(2):208-9. doi : AD-02-2003-130-2-0151-9638 101019-ART15.

11. Benson E. Bupropion-induced hypersensitivity reactions. Med J Aust. 2001;174(12):650-1.

12. Olsen NJ. Drug-induced autoimmunity. Best Pract Res Clin Rheumatol. 2004;18(5):677-88.

13. Aguirre Zamorano MA1, López Pedrera R, Cuadrado Lozano MJ. Drug-induced lupus. Med Clin (Barc). 2010;135(3):124-9. doi: 10.1016/j.medcli.2009.04.035.

14. Love LA. New environmental agents associated with lupus-like disorders. Lupus. 1994;3(6):467-71.

15. Shakoor N, Michalska M, Harris CA, Block JA. Druginduced systemic lupus erythematosus associated with etanercept therapy. Lancet. 2002;359(9306):579-80.

16. De Rycke L, Kruithof E, Van Damme N, Hoffman IE, Van den Bossche N, Van den Bosch F, Veys EM, De Keyser F. Antinuclear antibodies following infliximab treatment in patients with rheumatoid arthritis or spondylarthropathy. Arthritis Rheum. 2003;48(4):101523.

17. Borchers AT, Keen CL, Gershwin ME. Drug-induced lupus. Ann N Y Acad Sci. 2007;1108:166-82.

18. Yung RL, Johnson KJ, Richardson BC. New concepts in the pathogenesis of drug-induced lupus. Lab Invest. 1995;73(6):746-59.
19. Sen D, Isenberg DA. Antineutrophil cytoplasmic autoantibodies in systemic lupus erythematosus. Lupus. 2003;12(9):651-8.

20. Vasoo S. Drug-induced lupus: an update. Lupus. 2006;15(11):757-61.

21. Jumez N, Dereure O, Bessis D, Guillot B. Flare of cutaneous lupus erythematosus induced by bupropion (Zyban). Dermatology. 2004;208(4):362.

22. Cassis TB, Callen JP. Bupropion-induced subacute cutaneous lupus erythematosus. Australas J Dermatol. 2005 Nov;46(4):266-9.

23. Hannah CE, Little AJ, Wanat KA, Fairley JA. DrugInduced Cutaneous Lupus Erythematosus: A Case Series of Five Patients with Bupropion-Associated Disease. J Clin Rheumatol. 2018. doi: 10.1097/ RHU.0000000000000882.

24. Barile-Fabris L, Hernández-Cabrera MF, BarraganGarfias JA. Vasculitis in systemic lupus erythematosus. Curr Rheumatol Rep. 2014;16(9):440. doi: 10.1007/ s11926-014-0440-9.

25. Ramos-Casals M, Nardi N, Lagrutta M, Brito-Zerón P, Bové A, Delgado G, Cervera R, Ingelmo M, Font J. Vasculitis in systemic lupus erythematosus: prevalence and clinical characteristics in 670 patients. Medicine (Baltimore). 2006;85(2):95-104. 